\title{
Polyisoprene/Nanostructured Carbon Composites for Applications in Temperature Sensors
}

\author{
Maris Knite ${ }^{1}$, Sanita Zike ${ }^{2}$, Juris Zavickis ${ }^{3}$, Artis Linarts ${ }^{4}{ }^{1-4}$ Riga Technical University
}

\begin{abstract}
The studies of electrical properties of the polyisoprene (PI) matrix/high structure carbon black (HSCB) composites $(\mathrm{PCBC})$ with various concentrations $(8,9,10$ and 11 mass parts) of filler have been carried out in the temperature interval of $90 \mathrm{~K}-330 \mathrm{~K}$. In this paper we focus on the investigation of direct current (DC) conductivity in a low-temperature region with negative temperature coefficient of resistivity (NTCR). It has been proven that variable range hopping (VRH) conduction is dominated by hopping of carriers among localized states in a low-temperature range. At higher temperatures the nearest neighbour hopping (NNH) conductivity or constant range hopping charge transport takes place. The reversibility as well as small hysteresis of resistance change versus temperature indicates prospective temperature sensor application for PCBC.
\end{abstract}

Keywords: polyisoprene, high structure carbon black, composite, charge hopping conductivity, temperature sensor

\section{INTRODUCTION}

In recent decades, there have been an increasing number of papers devoted to the elaboration as well as investigation of polymer/conductive filler composites (PCFC) as electrically active materials for different sensor applications. The electrical resistance of PCFC is sensitive to various external force parameters [1-6], such as pressure, deformation, gaseous environment and temperature. The above-mentioned polymer composites promise to replace conventional rigid inorganic sensors in certain applications due to their flexibility and ease of processing. Resistivity of polymers may be tuned by the introduction of conductive filler particles. A continuous insulator-conductor transition is observed in two-component systems at a gradual increase in the number of randomly dispersed conductor particles in an insulator matrix. Most often such transitions, called percolation transitions, are described by the model of statistical percolation [7-8]. In the vicinity of the percolation transition, the electrical conductivity $\sigma$ of the composites changes under the smallest deformation of the matrix manifesting the strain. The change in the electrical resistance under strain can be explained on the microscopic level as a result of changes in the percolation structure of the network of conductive particles.

Irreversible change in the electrical resistance at deformation by stretch or pressure has been found in the case of micro-size particles of good conductors as well as low structure carbon black (LSCB) [2-4].

New interesting properties are expected in case the composite contains dispersed nano-size conducting particles [9-13]. Polymer-electro-conductive nanostructure composites offer attractive alternatives for developing a new generation of flexible large-size sensors because of their superior mechanical and electrical properties.

Recently, we have reported our investigations of several distinguished sensing effects inherent to polyisoprene matrix/ high structure carbon black (HSCB) composites (PCBC) with filler concentration values adherent to the region of percolation threshold. These effects are the dependence of electrical resistance versus mechanical strain (tensile strain and compressive strain sensing $[13,14])$, as well as changes in resistance in the presence of organic solvent vapours (chemical sensing [14, 15]).

The aim of this paper is to investigate and discuss the electric charge transport properties of the above-mentioned $\mathrm{PCBC}$ in the temperature range from $90 \mathrm{~K}$ up to $280 \mathrm{~K}$. Different models for describing the temperature dependence of electric conductivity of polymer/conductive particle composites, which have been found in the scientific literature, are to be considered during discussion of our experimental results.

\section{EXPERIMENTAL SECTION}

The PCBC composites have been made by mixing highly structured extra-conductive HSCB Degussa Printex XE2TM and necessary curing ingredients - sulphur, stearic acid, Ncyclohexyl-2-benzothiazole sulfenamide and zinc oxide - into raw natural rubber Thick Pale Creppe ${ }^{\mathrm{TM}}$ polyisoprene matrix. In our approach this was done using cold rolls under room temperature. Samples with different HSCB concentrations (8, 9, 10, 11 mass parts (m.p.) per 100 mass parts of natural rubber) were made by vulcanizing in hot stainless steel mould. $50 \mu \mathrm{m}$ thick brass foil mould inserts were used as electrodes. The inserts were cleaned using sandpaper and ethanol before insertion. Different vulcanization pressures were used to determine the pressure influence on the piezoresistive properties. The best piezoresistive properties were shown by the samples vulcanised at pressure of $3 \mathrm{Mpa}$. These samples were used for the electrical resistance measurements at various ambient temperatures. Flat $\sim 1 \mathrm{~mm}$ thick sticks of PCBC were made. These sticks were cut into flat pieces with dimensions of 10x15 mm using a high-speed diamond disk cutter to avoid unnecessary squeezing.

A custom-made liquid nitrogen thermostat was used for making measurements of resistivity at different temperatures. The thermostat consisted of a brass cylinder, where the sample and platinum thermo-resistor were placed. The platinum resistor was used to measure temperature. Measurements were made in dry helium atmosphere. Data were collected with Agilent 34970A data logger. 


\section{RESULTS AND DISCUSSION}

The volume resistance $\mathrm{R}$ of $\mathrm{PCBC}$ with 8, 9, 10 and 11 m.p. of HSCB was measured in the temperature range of $90 \mathrm{~K}-335$ K. Many cycles of measurements of the DC electrical resistance as a function of temperature were made for each type of PCBC. In Fig. 1, the experimental data of $\mathrm{R}(\mathrm{T})$ for PCBC with 9 m.p. of HSCB are represented.

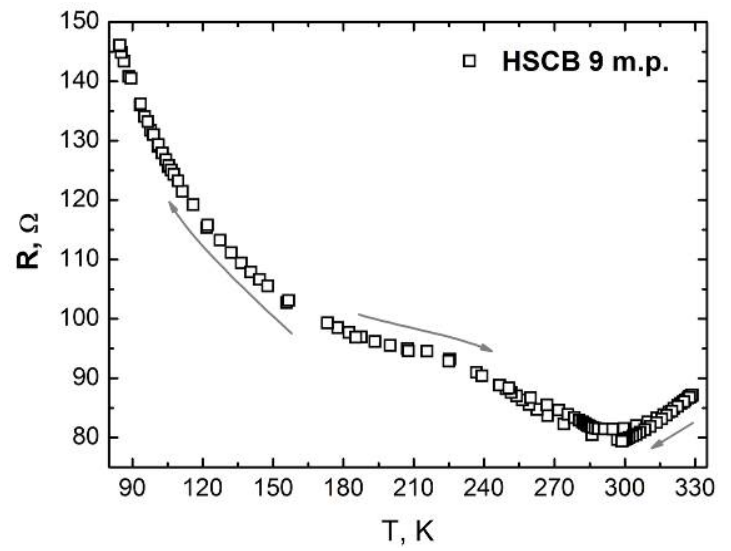

Fig. 1. The volume resistivity of PCBC sample with 9 mass parts of HSCB as a function of temperature during cooling and heating

One can distinguish three temperature regions: region I (90 $\mathrm{K}-160 \mathrm{~K})$; region II $(230 \mathrm{~K}-270 \mathrm{~K})$ and region III $(280 \mathrm{~K}-335$ $\mathrm{K})$ with apparently different charge transport mechanisms. In this paper, we consider region I and region II (low temperature investigations).

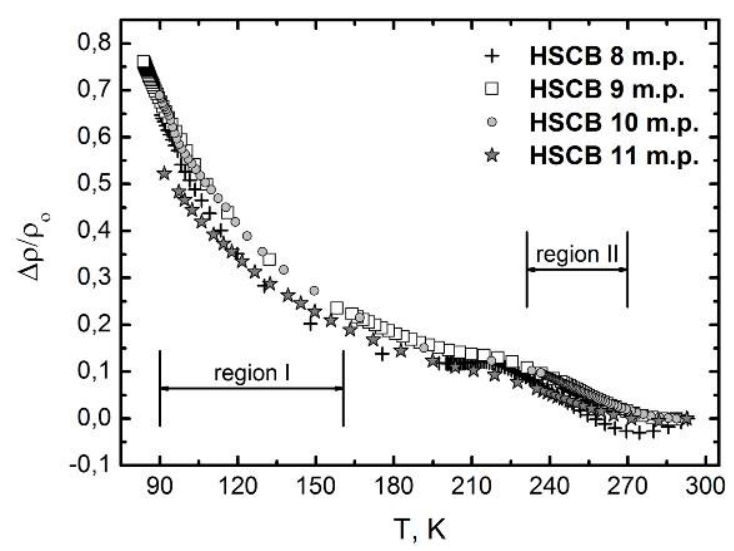

Fig. 2. The relative change in specific electrical resistivity as a function of temperature during cooling for the $\mathrm{PCBC}$ samples with different mass parts of HSCB

The relative resistivity $\Delta \rho / \rho_{0}$ as a function of temperature calculated from the experimental results is provided in Fig. 2 for all the investigated composites. It is seen that the character of the resistivity temperature dependence is the same for all samples with different HSCB concentrations. Fig. 3 shows a plot of the logarithm of electrical conductivity versus the temperature inverse for all the investigated samples.

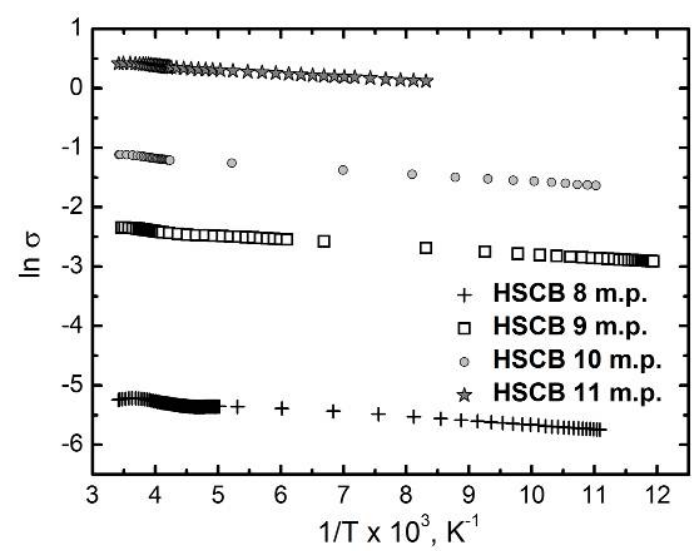

Fig. 3. The $\ln \sigma$ as a function of $1 / \mathrm{T}$ for the PCBC with different mass parts of HSCB

Comprehensive picture of electric charge transport properties in disordered semiconductor materials, including conductivity behaviour versus temperature, is provided by Mott [16]. He first pointed out that states in the band tails would be localized and that energies of localized and extended (non-localized) states would be separated by sharp energy $E_{c}$, known as a mobility edge. For the conduction band of a nonmetal, the existence of a mobility edge means that the lowest states have become traps, and conduction normally will be provided by electrons excited to the mobility edge $E_{c}$. Thus, if the Fermi level lies below the mobility edge $E_{c}$, it is shown by Mott [16] that conduction may be of two kinds:

1. By thermally activated hopping of an electron in occupied state with energy below $\mathrm{E}_{\mathrm{F}}$. Electron receives energy from a phonon, which enables it to move to a nearby state above $\mathrm{E}_{\mathrm{F}}$. The electron always is supposed to move to the nearest empty centre [16] and the expression for conductivity is as follows:

$$
\sigma=\sigma_{0} \exp \left(-\frac{\varepsilon}{k T}\right)
$$

The $\varepsilon$ is of the form $\varepsilon \sim 1 / N\left(E_{F}\right) a_{3}$, where $a$ is the distance between the nearest neighbours. This mechanism is also known as the Nearest-Neighbour Hopping (NNH) model [16].

2. Mott [16] first pointed out that at low temperatures the most frequent hopping process would not be to the nearest neighbour. This form of conduction is called the Variable Range Hopping (VRH). It has been observed frequently in both doped crystalline semiconductors and amorphous materials, and the temperature dependence of conductivity is given in the following form $[16,17]$ :

$$
\sigma T^{\frac{1}{2}}=\sigma_{0} \exp \left(-\left(\frac{T_{0}}{T}\right)^{\frac{1}{4}}\right)
$$

where the parameter $\sigma_{0}$ can be considered the limiting value of conductivity at infinite temperature, $\mathrm{T}_{0}$ is the characteristic temperature that determines the thermally activated hopping among localized states at different energies and is considered a 
measure of disorder $[17,18]$. VRH mechanism is a phononassisted charge carrier transport process.

Thus, the VRH is expected to be the adequate conductivity mechanism for temperature region I, and the NNH should be the mechanism for the temperature region II. The applicability of the VRH model is usually examined by plotting the experimental results by Equation 2 in the form of $\ln \left(\sigma T^{1 / 2}\right)=$ $F\left(T^{1 / 4}\right)$, where they should be well fitted using linear dependence. In general, the fitting quality of the least square fitted curves provides information about the nature of the charge transport as well as indicates the dimensionality of the process.

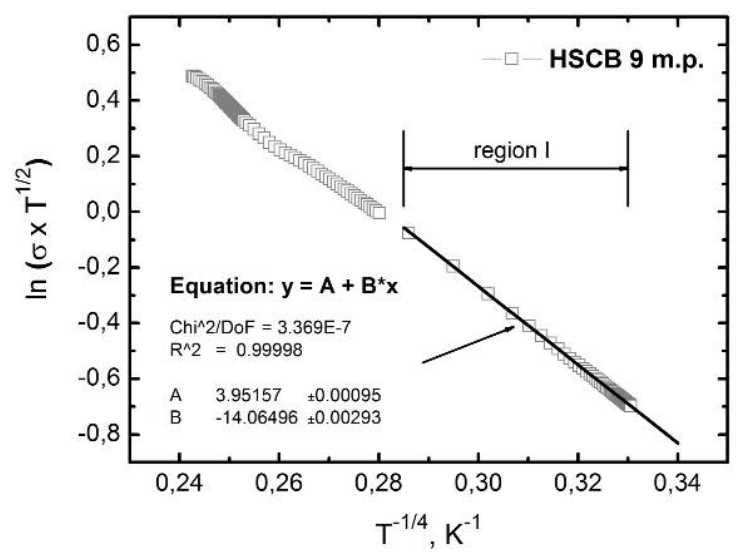

Fig. 4. The $\ln \left(\sigma x T^{1 / 2}\right)$ as a function of time inverse for PCBC with 9 mass parts of HSCB, well fitted with a linear function in temperature region I. According to Equation 2, the subsistence of VRH mechanism has been proven in region I.

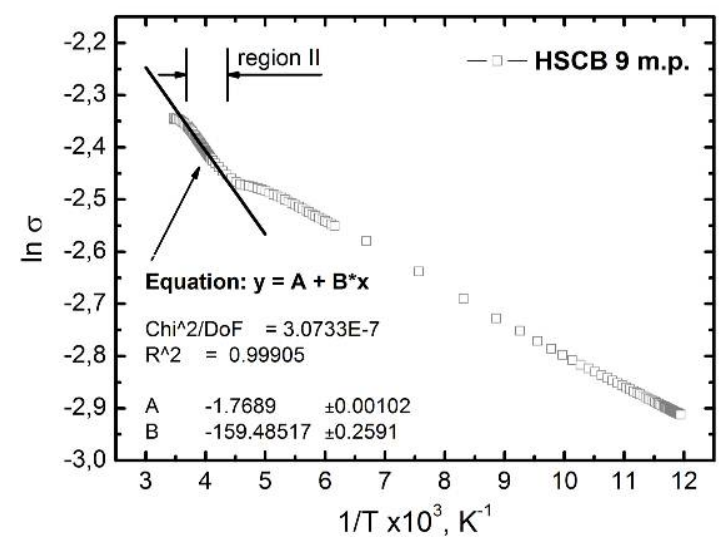

Fig. 5. The $\ln \sigma$ as a function of time inverse for PCBC with 9 mass parts of HSCB, well fitted with a linear function in temperature region II. According to Equation 1, the subsistence of NNH mechanism has been proven in region II. Chi refers to square deviation of fitted data from experimental results.

Fig. 4 shows the rigorous least square fitted curve by Equation 2 for PCBC with 9 m.p. of HSCB for temperature region $\mathrm{I}$. Now it is clearly seen that the VRH mechanism predominates in temperature region I. On the contrary, Fig. 5 demonstrates that in higher temperature region II the $\sigma(T)$ better fits by Equation 3, i.e., the NNH mechanism prevails in this temperature range. Thus, at higher temperatures the conductivity exhibits a thermally activated process and can be described by Equation 1. In such a way, the dominance of variable range hopping charge transport mechanism changes to the prevalence of fixed range hopping charge transport mechanism approximately at $230 \mathrm{~K}$ (Fig. 2).

The VRH model has been found as the main conductivity mechanism at a lower temperature region in many studies of conductive polymer composites [17, 19, 22]. Psarras [17] used two different hopping models to explain the charge transport properties of bisphenol type epoxy resin and iron powder composites - the VRH model and the Random Free-Energy Barrier (RFEB) model (also referred as the symmetric hopping model) proposed by Dyre [20, 21].

Saravanan et al. [19] pointed out that the VRH mechanism could be used in case of tetrameric cobalt phthalocyanine and polyaniline composites. Elimat et al. [22] also found a good agreement of experimental data with the VRH model for poly(methyl methacrylate)/carbon black composites.

\section{CONCLUSIONS}

The electrical conductivity of PCBC has been investigated. It has been found out that within the temperature range of 90 $\mathrm{K}$ to $280 \mathrm{~K}$ there are two mechanisms of conduction involved. One can distinguish two temperature regions: region I (90 K$160 \mathrm{~K})$ and region II (230 K-280 K) with apparently different charge transport mechanisms. For region $\mathrm{I}$, the most appropriate charge transport mechanism is believed to be Variable Range Hopping. It has been considered that the Nearest Neighbour Hopping or constant range hopping charge transport is dominant during temperature region II. This is also proven by analysing different activation energies for temperature regions I and II. The reversibility as well as small hysteresis of resistance change versus temperature indicates prospective temperature sensor application for PCBC.

\section{ACKNOWLEDGMENTS}

The research has been supported by the Latvian National Research Programme IMIS.

\section{REFERENCES}

1. Narkis, M., Ram, A., Flashner, F. Electrical Properties of Carbon Black Filled Polyethylene. Polymer Engineering Science, 1978, vol. 18, p. 649563. http://dx.doi.org/10.1002/pen.760180808

2. Aneli, J.N., Zaikov, G.E., Khananashvili, I.M.. Effects of Mechanical Deformations on the Structurization and Electric Conductivity of Electric Conducting Polymer Composites. Journal of Applied Polymer Science, 1999, vol. 74, p. 601-621. http://dx.doi.org/10.1002/(SICI)10974628(19991017)74:3<601::AID-APP14>3.0.CO;2-K

3. Zhang, X.W., Pan, Y., Zheng, Q., Yi, X.S., Time Dependence of Piezoresistance for the Conductor-Filled Polymer Composites. Journal of Polymer Science Part B: Polymer Physics, 2000, vol. 38, p. 2739-2749. http://dx.doi.org/10.1002/10990488(20001101)38:21<2739::AID-POLB40>3.0.CO;2-O

4. Das, N.C., Chaki, T.K., Khastgir, D., Effect of Axial Stretching on Electrical Resistivity of Short Carbon Fibre and Carbon Black Filled Conductive Rubber Composites. Polymer International, 2002, vol. 51, p. 156-163. $\quad$ http://dx.doi.org/10.1002/pi.811.abs http://dx.doi.org/10.1002/pi.811 
5. Wu, T.M., Cheng, J.C., Morphology and Electrical Properties of Carbon-black-filled Poly( $\epsilon$-caprolactone)/poly(vinyl butyral) Nanocomposites. Journal of Applied Polymer Science, 2003, vol. 88, p. 1022-1033. http://dx.doi.org/10.1002/app.11766

6. Ryan, A., Shevade, A.V., Zhoud, H., Homer, M.L., Polymer-Carbon Black Composite Sensors in an Electronic Nose for Air-Quality Monitoring, MRS bulletin, 2004,vol. 29, p. 714-719. http://dx.doi.org/10.1557/mrs2004.208

7. Staufer, D., Aharony, A. Introduction in to percolation theory, $4^{\text {th }} \mathrm{ed}$. London: Taylor. Francis, 1985

8. Roldugin, V.I., Vysotskii, V.V., Percolation Properties of Metal-Filled Polymer Films, Structure and Mechanisms of Conductivity. Progress in Organic Coatings, 2000, vol. 39, p. 81-100. http://dx.doi.org/10.1016/S0300-9440(00)00140-5

9. Flandin, L., Chang, A., Nazarenko, S., Hiltner, A., Baer, E., Effect of Strain on the Properties of an Ethylene-Octene Elastomer with Conductive Carbon Fillers. Journal of Applied Polymer Science, 2000, vol. 76, p. 894-905. http://dx.doi.org/10.1002/(SICI)10974628(20000509)76:6<894::AID-APP16>3.0.CO;2-K

10. Flandin, L., Brechet, Y., Cavaille, J.Y., Electrically Conductive Polymer Nanocomposites as Deformation Sensors. Composite Science and Technology, 2001, vol. 61, p. 895-901. http://dx.doi.org/10.1016/S0266-3538(00)00175-5

11. Knite, M., Teteris, V., Polyakov, B., Erts, D., Electric and Elastic Properties of Conductive Polymeric Nanocomposites on Macro- and Nanoscales. Material Science and Engineering C, 2002, vol. 19, p. 15-19. http://dx.doi.org/10.1016/S0928-4931(01)00410-6

12. Knite, M., Teteris, V., Kiploka, A., The Effect of Plasticizing Agent on Strain-Induced Change of Electric Resistivity of Carbon-Polyisoprene Nano-composites. Material Science and Engineering C, 2003, vol. 23, p. 787-790. http://dx.doi.org/10.1016/j.msec.2003.09.076

13. Knite, M., Teteris, V., Kiploka, A., Kaupuzs, J., Polyisoprene-Carbon Black Nanocomposites as Strain and Pressure Sensor Materials. Sensors and Actuators A, 2004, vol. 110, p. 142-149. http://dx.doi.org/10.1016/j.sna.2003.08.006

14. Knite, M., Klemenok, I., Shakale, G., Teteris, V., Polyisoprene-Carbon Nano-Composites for Application in Multifunctional Sensors. Journal of Alloys and Compounds, 2007, vol. 434-435, p. 850-853. http://dx.doi.org/10.1016/j.jallcom.2006.08.098

15. Knite, M., Ozols, K., Shakale, G., Teteris, V., Polyisoprene and High Structure Carbon Nanoparticle Composite For Sensing Organic Solvent Vapours. Sensors and Actuators B, 2007, vol. 126, p. 209-213. http://dx.doi.org/10.1016/j.snb.2006.11.049

16. Mott, S N. Conduction in Non-Crystalline Materials, 2nd ed. Oxford: Oxford University Press Inc, 1993. 146 p.

17. Psarras, G.C., Hopping Conductivity in Polymer Matrix-Metal Particles Composites. Composites: Part A, 2006, vol. 37, p. 1545-1553. http://dx.doi.org/10.1016/j.compositesa.2005.11.004

18. Mandal, P., Neumann, A., Jansen, A.G.M., Wider, P., Temperature and Magnetic-Field Dependence of the Resistivity of Carbon-Black Polymer Composites. Physical Review B, 1997, vol. 55, p. 452-456. http://dx.doi.org/10.1103/PhysRevB.55.452

19. Saravanan, S., Anantharaman, M.R., Venkatachalam, S., Structural and Electrical Studies on Tetrameric Cobalt Phthalocyanine and Polyaniline Composites. Material Science and Engineering B, 2006, vol. 135, p. 113-119. http://dx.doi.org/10.1016/j.mseb.2006.08.048

20. Dyre, J.C., The Random Free Energy Barrier Model for AC Conduction in Disordered Solids. Journal of Applied Physics, 1988, vol. 64, p. 24562469. http://dx.doi.org/10.1063/1.341681

21. Dyre, J.C., Shrøder, T.B., Universality of ac conduction in disordered solids. Reviews of Modern Physics, 2000, vol. 72, p. 873-892. http://dx.doi.org/10.1103/RevModPhys.72.873

22. Elimat, Z.M., Zihlif, A.M., Ragosta, G., PAN-Based Carbon Fibers/PMMA Composites: Thermal, Dielectric, and DC Electrical Properties. Journal of Materials Science: Materials in Electronics, DOI 10.1007/s10854-012-0712-y http://dx.doi.org/10.1007/s10854012-0712-y

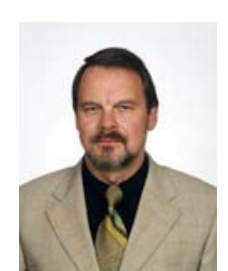

Maris Knite was awarded the Dr.habil.phys. by the Institute of Solid State Physics of the University of Latvia in 1999. His field of scientific interests includes: phase transitions and optical, thermo-optical, and electro-optical properties in both ferroelectrics and ferroelastics; laser-induced phase transitions in ferroelectric and silicide thin films.

Since 1999 he has been a FULL TIME PROFESSOR in physics of materials at the Institute of Technical Physics of Riga Technical University. Current scientific interests include design and investigation of electrically conductive polymer nanocomposites as prospective smart materials.

Currently he is the Head of Promotion Council 'RTU P-18' in Materials Science; COST expert In DC: Materials, Physical and Nanosciences; Member of EMRS, Member of EOS; as well as Corresponding Member, the Latvian Academy of Sciences, 2004, Diploma No. K-248

E-mail: maris.knite@,rtu.lv

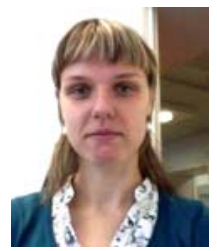

Sanita Zike has graduated from Riga Technical University in 2011 and holds the Master of Science degree in Materials Science.

Previous scientific experience comprised research of 1) nanostructured and flexible temperature and pressure sensitive sensors based on a polymer matrix; 2) impact damage of structural polymer matrix based composites, and currently 3) micro-mechanical polymer and polymer matrix based composite characterization. Sanita Zike has worked as a Research Assistant both at the Institute of Technical Physics and at the Institute of Materials and Structures, Riga Technical University. Currently she is a doctoral student at the Technical University of Denmark.

E-mail: sanita.zike@gmail.com

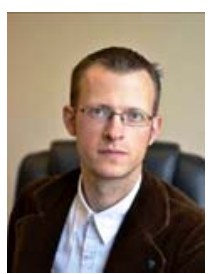

Juris Zavickis received his Dr.phys. in Material Physics in 2011 after defending the thesis on nanostructured elastomer-carbon composites with specific mechanoelectrical properties and strong piezoresistance.

Currently he is working as a LEADING RESEARCHER at the Institute of Technical Physics of Riga Technical University. His scope of expertise covers electrically percolative polymer composites, experimental physics, mechanic and electric measurements.

Since 2011 he has been the Vice President of the Latvian Society of Material Researchers; since 2010 he has been a Fellow of the Association of Young Scientists of Latvia; since 2009 he has been taking active participation in COST action NMP0902 COINAPO (Composites of Inorganic Nanotubes and Polymers).

E-mail: juris.zavickis@,rtu.lv

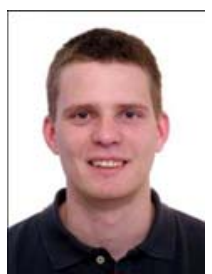

Artis Linarts received his Mg.sc.ing. in Materials Science in 2012; right now he is a doctoral student at the Faculty of Materials Science and Applied Chemistry of Riga Technical University. In 2010 he received SocratesErasmus mobility grant and spent an exchange semester at the Royal Institute of Technology (Sweden). His main fields of interest are electrically conductive elastomeric composites for pressure sensor application and the temperature influence on the piezoresistivity of polymer composite.

Since 2011 he has been a RESEARCH ASSISTANT at the Institute of Technical Physics of Riga Technical University.

E-mail: artis.linarts@,rtu.lv 
Māris Knite, Sanita Zīke, Juris Zavickis, Artis Linarts. Poliizoprēna/nanostrukturēta oglekḷa kompozīti pielietošanai temperatūras sensoros

Ar elektrovadošām dal̦inām pildīti polimērkompozīti pēdējā laikā arvien biežāk tiek izmantoti elektroaktīvu sensoru izgatavošanā. Tie ir salīdzinoši lokani, viegli izgatavojami un to elektriskās īpašības var modificēt, izmantojot dažāda veida un koncentrācijas elektrovadošās pildvielas.

Šajā rakstā eksperimentāli pētītas ar augstas struktūras oglekli pildīta poliizoprēna kompozīta elektriskās īpašības līdzstrāvas režīmā 90-330 K temperatūras intervālā. Izmantoti kompozīti ar 8, 9, 10 un 11 masas daḷām elektrovadošās pildvielas, kas visi uzrādīja negatīvu elektriskās pretestības temperatūras koeficientu pie zemām temperatūrām un pozitīvu elektriskās pretestības temperatūras koeficientu pie temperatūrām, kas augstākas par $280 \mathrm{~K}$. Tas nozīmē, ka zemās temperatūrās kompozītam piemīt pusvadītāja līdzstrāvas vadāmība, kas pie augstākām temperatūrām kḷūst metāliska. Lai izskaidrotu līdzstrāvas vadāmības mehānismu, tika pārbaudīti vairāki teorētiskie modeḷi. Pierādīts, ka pie zemas temperatūras kompozītā dominējošā ir Motta lādiņnesēju mainīga attāluma pārlekšanas vadāmības modelis, kas nodrošina lādiņnesēju pārlekšanu starp lokalizētiem enerǵijas līmeņiem. Paaugstinoties temperatūrai, diapazonā 230-250 K dominē tuvākā kaimiņa pārlekšanas jeb lādiṇnesēju nemainīga attāluma pārlekšanas vadāmība. Elektriskās vadāmības izmaiṇu atgriezeniskums un mazā histerēze norāda uz iespējām pielietot dotos kompozītus temperatūras sensoru izstrādē.

Марис Кните, Санита Зике, Юрис Завицкис, Артис Линартс. Композиты полиизопрена и наноструктурированного углерода для применения в сенсорах температуры

В последнее время наполненные электропроводящими частицами полимерные композиты все чаще применяют в изготовлении различных электронных сенсоров. Такого рода сенсоры относительно дешевле и проще изготовляются, к тому же их параметры можно легко модифицировать, варьируя видом и концентрацией наполнителя.

В этой статье экспериментально исследованы электричесие параметры постоянного тока для композитов полиизопрена и наноструктурированного углерода в температурном интервале 90 - 330 градусщв Кельвина. Все исследованные композиты проявили отрицательный температурный коэффициент сопротивления в интервале низких температур и полжительный температурный коэффициент сопротивления выше температуры 280 градусов Кельвина. В результате показано, что в интервале более низких температур преобладает прыжковая проводимость Мотта с переменной длиной, а прыжковая проводимость через ближайших соседей доминирует в температурном интервале 230 - 250 градусов Кельвина. Также показана возможность применения исследованных материалов в изготовлении температурных сенсоров. 